\title{
Fighting against COVID-19 and Fighting against Stigma: A Mini-review
}

\author{
Sorimuda Sarumpaet ${ }^{1 \star}$, Fotarisman Zaluchu ${ }^{1}$, Putri Chairani Eyanoer ${ }^{2}$, Novita Hasiani Simanjuntak ${ }^{3}$ \\ ${ }^{1}$ Department of Epidemiology, Universitas Sumatera Utara, Medan, North Sumatera, Indonesia; ${ }^{2}$ Department of Community \\ and Preventive Medicine, Universitas Sumatera Utara, Medan, North Sumatera, Indonesia; ${ }^{3}$ Department of Public Health, \\ Faculty of Medicine, Universitas HKBP Nommensen, Medan, North Sumatera, Indonesia
}

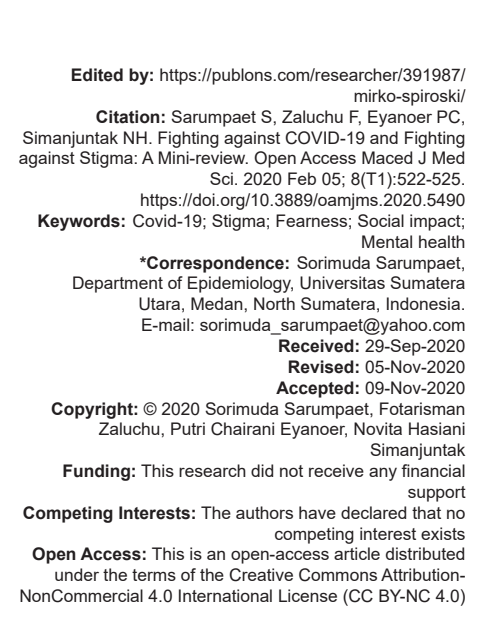

Introduction

COVID-19 is sweeping the world so fast. In only about 8 months, millions of people have been infected. The WHO said that globally more than 40 million people currently have been infected, with the number of deaths reaching more than 1 million people [1]. The global response continues to be carried out to find a vaccine which, unfortunately, has not been produced yet [2].

In accordance with the findings of health experts that COVID-19 is a disease that attacks multiple organs, the impact of COVID-19 is increasingly visible in many aspects. Apart from the economic impact, COVID-19 also shows another significant impact that is also dangerous, namely, social stigma. Sadly, this social stigma affects not only patients but also health workers and even COVID-19 survivors [3].

Therefore, the current world struggle is not only against the severe acute respiratory syndrome coronavirus 2 (SARS-CoV-2) virus but also against the stigma that accompanies the presence and spread of the virus. If, at this time, the SARS-CoV-2 virus could be identified by its method of spread, the social stigma would not be easy to overcome because it spreads through the social system in society.

\section{Social Context}

The definition of social stigma raised by Goffman explains the social situation that occurs by the presence of stigma. By stigmatization, there is an event that discredits a person from their usual condition, to be "a tainted, discounted one" [4]. As a social dimension, stigma does not occur in empty space but social interactions in a society. One of the causes of stigma is an excessive fear of something, which is not only due to physical things but also on the labeling of something/someone [5]. In other words, stigma cannot be separated from the ongoing social framing.

Since the onset of this pandemic, the emphasis on isolating patients has been voiced by the WHO [6]. The quarantine procedure is carried out to prevent the transmission of COVID-19 to healthy groups of people. 
Evidence-based treatment measures recommend that at least isolate the patient if placement in a special quarantine location is not possible.

However, unfortunately, the limitation on these patients has become a framing that has resulted in social stigma. Patients are labeled dangerous so that unconsciously efforts to prevent disease transmission have created excessive fear and encouraged social stigma [7]. Although the $\mathrm{WHO}$ has provided an early warning that the current enemy of humans is not only the virus that causes COVID-19 but also stigmatization [8], this stigma has spread everywhere and created a huge impact that was never previously anticipated.

Apart from framing the sufferer, one of the causes of this stigma lies in human psychology. It is normal for humans to develop protection for themselves [9]. This desire encourages humans to bring up self-defense mechanisms from something outside themselves. When people with COVID-19 are perceived to have a virus that can threaten someone's safety, then automatically, other people will do something, including showing social stigma. As warned by the WHO that in an outbreak situation, "people are labeled, stereotyped, discriminated against, treated separately, and/or experience loss of status due to a perceived link with a disease" [10].

\section{Impacts}

As a social problem, stigma has a very significant serious impact as does other diseases such as tuberculosis [9], [10], [11] or HIVIAIDS [12], [13], [14], [15]. At least, due to the stigma that exists, people who are exposed to COVID-19 tend to hide their illness. As a result, they will not immediately seek treatment when it is really needed. In the end, they will not make behavioral changes, which should be needed in the appropriate conditions [16]. The Indonesian Ministry of Health stated that the high number of deaths due to COVID-19 was influenced by the delay in handling patients due to this social stigma [17]. These conditions are clearly very dangerous because the transmission of COVID-19 in the community will be hidden, like an iceberg phenomenon. COVID-19 will spread silently in society and cause tragic deaths.

The big impact of stigma that is still continues to occur is also seen in the occurrence of injustice to a person or community group [18]. The Jakarta Post, in its August 30, 2020 edition, reveals the story of a young woman who recovered from Covid-19. She experienced a social stigma that is so obvious. When she returned to her place of work, her friends greeted her so coldly, her coworkers avoided her, even some of them no longer wanted to have lunch with her. Sadly, she was blamed for the infection of some of her colleagues [19].
The public's fear of COVID-19 infection can be seen from the stories of the Westerdam passengers, as reported by the New York Times. When one passenger was found positive, more than 1500 others had to be tested. While waiting for the test results, not a single country was willing to accept the ship due to fears of the spread of COVID-19. Some of the ship's passengers, who then got off the ship with negative test results, actually received rejection and even hate speech from their own neighbors [20].

Stigmatization also seems to eliminate our human feelings. Facts show that many patients who died due to COVID-19 were refused burial by the public. People still think that the bodies of people who died due to COVID-19 are still dangerous, so they do not want burials in their residential areas [21]. The rejection of the patients who died due to COVID-19 is not much different from the rejection of those who are detected positive for COVID-19 even though they survived the disease.

The fear of this disease is, indeed, natural, and considering that this virus is still not well recognized at the beginning of its occurrence. Experts and the public do not have a clear understanding of this virus, including the method of spread and its effects. Hence, it is no wonder at the beginning of the outbreak of COVID-19; this stigma spreads so fast. However, it is very unfortunate that, over time, the stigma that occurs, which does not decrease, it even affects health workers [22].

Medical personnel who serve patients in hospitals experience a stigma that is sometimes so terrible because they are thought to be transmitting the disease. Therefore, in many places, they dare not wear their medical clothes due to the pressure that appears on them. Even nurses and doctors not only accept social pressure, even violent behavior [23].

This is clearly a very big problem. At present, the whole world needs medical personnel. In some places, the government has even been forced to take emergency measures by sending medical students who have not yet completed their education to serve the increasing number of patients. Health workers are exhausted due to the number of cases they have to handle, while the equipment available is very limited. There are even doctors who kill themselves because they are unable to see the suffering in their patients [24]. However, it is during times of crisis as well, stigma occurs on health workers and exacerbates emergency situations like this.

Seven months after the first case was reported, the stigma was still emerging. In West Java, Indonesia, for example, the houses of COVID-19 patients are fenced off by neighbors. Neighbors think that they can get the virus [25]. 


\section{Against Stigma}

The presence of COVID-19 has presented a huge challenge to policymakers in the field of public health. The COVID-19 pandemic has opened our minds to various problems that we never imagined would happen. The consequences of this stigma should encourage us to start thinking about mental health development efforts, far beyond what has been considered the traditional area of mental health. At present, the mental health of patients is considered very important. Many health facilities have developed mentoring efforts with patients to prevent the impact of this stigma on their mental health. However, people's mental health is something that cannot be ignored [26]. Of course, the stigma begins with people's insufficient knowledge of COVID-19. Therefore, after 10 months have passed, even though something is still unknown about this disease, more adequate information should be able to be conveyed to the public. Fighting the stigma caused by COVID-19 also means fighting the circulation of incorrect and even misleading information, especially relating to patients and their families, and even medical personnel [16], [24].

The government must provide a special information channel about COVID-19. This has been taken by many countries by providing important information regarding the prevention and handling of COVID-19 from the household level [25], [26], [27]. However, the government should also routinely enter into citizens' social media channels by conveying accurate information and countering misleading information circulating in the community. In situations where restrictions are imposed, social media is the community's top choice, and the problem of stigma unfortunately often originates there.

Instead of allowing the public to just accept misinformation, the health authorities should also encourage efforts to increase the social strength of the community. The community must be motivated so that they are actively motivated to help, pay attention, and give respect to their neighbors, their acquaintances and even anyone affected by COVID-19 because maybe they will need the same thing in the future. Increasing the social cohesion of the community is also a challenge that requires consistency and seriousness of the government in overcoming this stigma.

Therefore, involving community and religious leaders is essential [28], [29], [30], [31]. Their involvement will accelerate the eradication of this stigma. They can tell the public not to give negative labels to patients; they can even convey correct information for the public to know. They can also spread the right message about COVID-19 so that people know what is right and what they should avoid. In one region in Indonesia, for example, food and basic necessities for positive patients are even provided by religious groups. This created positive support for the patients [32]. Inevitably, there are too many opportunities to raise our awareness of the dangers that follow COVID-19.

\section{Conclusion}

Stigma is a serious problem that greatly affects efforts to control and handle COVID-19. Therefore, various efforts must be made to prevent the stigmatization of patients, health workers, and people infected with COVID-19.

\section{References}

1. World Health Organization. WHO Coronavirus Disease (COVID-19) Dashboard. Geneva: World Health Organization; 2020. Available from: https://www.covid19.who.int. [Last accessed on 2020 Oct 22].

2. World Health Organization. The Push for a Covid-19 Vaccine. Geneva: World Health Organization; 2020. Available from: https:// www.who.int/emergencies/diseases/novel-coronavirus-2019/ covid-19-vaccines. [Last accessed on 2020 Sep 14].

3. Bagcchi S. Stigma during the COVID-19 pandemic. Lancet Infect Dis. 2020;20(7):782

PMid:32592670

4. Goffman E. Stigma: Notes on the Management of Spoiled Identity. Englewood Cliffs, NJ: Prentice Hall; 1963.

5. Ahmedani BK. Mental health stigma: Society, individuals, and the profession. J Soc Work Values Ethics. 2011;8(2):41-416. PMid:22211117

6. World Health Organization. Media Briefing Director General. Geneva: World Health Organization; 2020. Available from: https://www.who.int/dg/speeches/detail/who-director-generals-opening-remarks-at-the-media-briefing-on-covid-19---11march-2020. [Last accessed on 2020 Sep 27]. https://doi. org/10.1093/ww/9780199540884.013.u23682

7. Bardfam R, Zandifar A. Stigma over COVID-19; new conception beyond individual sense. Arch Med Res. 2020;51(6):593-4. https://doi.org/10.1016/j.arcmed.2020.05.006 PMid:32467051

8. World Health Organization. Media Briefing Director General Geneva: World Health Organization; 2020. Available from: https://www.who.int/dg/speeches/detail/who-director-generals-opening-remarks-at-the-media-briefing-on-covid-19---28feburary-2020. [Last accessed on 2020 Feb 28]. https://doi. org/10.1093/ww/9780199540884.013.u7971

9. Dwinantoaji $\mathrm{H}$, Sumarni DW. Human security, social stigma, and global health: The COVID-19 pandemic in Indonesia. J Med Sci. 2020;52(3):158-65. https://doi.org/10.19106/ jmedscisi005203202014

10. World Health Organization. A Guide to Preventing and Addressing Social Stigma Associated with COVID-19. Geneva: World Health Organization; 2020. Available from: https://www.who. int/publications/m/item/a-guide-to-preventing-and-addressingsocial-stigma-associated-with-covid-19. [Last accessed on 2020 Oct 22]. https://doi.org/10.20944/preprints202007.0051.v1

11. Gudeva Nikovska D, Tozija F. Stigma associated with tuberculosis disease in republic of Macedonia-results from a cross-sectional 
study. Open Access Maced J Med Sci. 2014;2(4):640-4. https:// doi.org/10.3889/oamjms.2014.115

12. Juniarti N, Evans D. A qualitative review: The stigma of tuberculosis. J Clin Nurs. 2011;20(13-14):1961-70. https://doi. org/10.1111/j.1365-2702.2010.03516.x

PMid:21040040

13. Gosoniu GD, Ganapathy S, Kemp J, Auer C, Somma D, Karim F, et al. Gender and socio-cultural determinants of delay to diagnosis of TB in Bangladesh, India and Malawi. Int J Tuberc Lung Dis. 2008;12(7):848-55.

PMid: 18544215

14. Pignatelli S, Simpore J, Pietra V, Ouedraogo L, Conombo G, Saleri $\mathrm{N}$, et al. Factors predicting uptake of voluntary counselling and testing in a real-life setting in a mother-and-child center in Ouagadougou, Burkina Faso. Trop Med Int Health. 2006;11(3):350-7. https://doi. org/10.1111/j.1365-3156.2006.01564.x

PMid: 16553915

15. Hubach RD, Dodge B, Li MJ, Schick V, Herbenick D, Ramos WD, et al. Loneliness, HIV-related stigma, and condom use among a predominantly rural sample of HIV-positive men who have sex with men (MSM). AIDS Educ Prev. 2015;27(1):72-83. https://doi. org/10.1521/aeap.2015.27.1.72

PMid:25646731

16. International Federation of Red Cross and Red Crescent Societies, UNICEF, World Health Organization. A Guide to Preventing and Addressing Social Stigma Associated with COVID-19. Geneva: World Health Organization; 2020. Available from: https://www.who.int/publications/m/item/aguide-to-preventing-and-addressing-social-stigma-associatedwith-covid-19? [Last accessed on 2020 Sep 27]. https://doi. org/10.1017/s0020860400090276

17. Ministry of Health. Kemenkes: Stigma Berkontribusi Terhadap Tingginya Angka Kematian COVID-19; 2020. Available from: https://www.covid19.go.id/p/berita/kemenkes-stigmaberkontribusi-terhadap-tingginya-angka-kematian-covid-19. [Last accessed on 2020 Sep 27].

18. Sotgiu G, Dobler CC. Social stigma in the time of coronavirus disease 2019. Eur Respir J. 2020;56(2):23-5.

PMid:32631833

19. Syakriah A. For Some Indonesians, COVID-19 Stigma Worse than Disease. Jakarta, Indonesia: The Jakarta Post; 2020. Available from: https://www.thejakartapost.com/ news/2020/08/30/for-some-indonesians-covid-19-stigmaworse-than-disease.html. [Last accessed on 2020 Aug 30].

20. Stockman F. What It's Like to Come Home to the Stigma of Coronavirus. New York: The New York Times Company; 2020. Available from: https://www.nytimes.com/2020/03/04/us/stigmacoronavirus.html. [Last accessed on 2020 Mar 04].

21. Sutrisno B. Families, Health Workers Face Stigma as Fear Overtakes Communities. Jakarta, Indonesia: The Jakarta Post; 2020. Available from: https:// www.thejakartapost.com/news/2020/03/29/ families-health-workers-face-stigma-as-fear-overtakescommunities.html. [Last accessed on 2020 Mar 29].

22. Villa S, Jaramillo E, Mangioni D, Bandera A, Gori A, Raviglione MC. Stigma at the time of the COVID-19 pandemic. Clin Microbiol Infect. 2020;6:1450-2. https://doi.org/10.1016/j.cmi.2020.08.001 PMid:32777361

23. Semple K. "Afraid to Be a Nurse": Health Workers Under Attack. New York: The New York Times; 2020. https://www.nytimes. com/2020/04/27/world/americas/coronavirus-health-workersattacked.html. [Last accesed on 2020 Apr 27].

24. Knoll C, Watkins A, Rothfeld M. I Couldn't Do Anything': The Virus and an E.R. Doctor's Suicide. New york: The New York Times; 2020. Available from: Available from: https://www.nytimes. com/2020/07/11/nyregion/lorna-breen-suicide-coronavirus.html. [Last accessed on 2020 Jul 11].

25. Lamb K, Widianto S. Coronavirus Stigma Runs Deep and Dangerous in Indonesia. London: Reuters News Organization Company; 2020. Available from: ???. [Last accessed on 2020 Sep 17].

26. Moreno C, Wykes T, Galderisi S, Nordentoft M, Crossley N, Jones $\mathrm{N}$, et al. How mental health care should change as a consequence of the COVID-19 pandemic. Lancet Psychiatry. 2020;7(9):813-24. https://doi.org/10.1016/ s2215-0366(20)30307-2

27. The Lancet. COVID-19: Fighting panic with information. Lancet. 2020;395(10224):537. https://doi.org/10.1016/ s0140-6736(20)30379-2

PMid:32087777

28. Centers for Disease Control and Prevention. Guidance for Cleaning and Disinfecting. Atlanta: Centers for Disease Control and Prevention; 2020. Available from: https://www.cdc.gov/ coronavirus/2019-ncov/community/cleaning-disinfectingdecision-tool.html. [Last accessed on 2020 Sep 14]. https://doi. org/10.1108/rr-08-2016-0213

29. Centers for Disease Control and Prevention. Cleaning and Disinfection for Households. Atlanta: Centers for Disease Control and Prevention; 2020. Available from: https://www. cdc.gov/coronavirus/2019-ncov/prevent-getting-sick/cleaningdisinfection.html. [Last accessed on 2020 Sep 14]. https://doi. org/10.1108/rr-08-2016-0213

30. World Health Organization. COVID-19 Strategic Preparedness and Response Plan, Country Preparedness and Response Status for COVID-19. Geneva: World Health Organization; 2020. Available from: https://www.who.int/publications $/ \mathrm{m} / \mathrm{item} /$ updated-country-preparedness-and-response-status-for-covid19-as-of-19-march-2020. [Last accessed on 2020 Aug 29]. https://doi.org/10.1186/s41182-020-00240-9

31. Mahmud A, Islam MR. Social stigma as a barrier to Covid19 responses to community well-being in Bangladesh. Int J Community Well Being. 2020;10:1-7. https://doi.org/10.1007/ s42413-020-00071-w

32. Sulistiadi W, Rahayu S, Harmani N. Handling of public stigma on covid-19 in Indonesian society. Kesmas Natl Public Health J. 2020;15(2):69-75. https://doi.org/10.21109/kesmas.v15i2.3909 